\title{
海城および唐山地震の先行現象
}

\author{
東京工業大学理学部応用物理学教室 鄭 中 \\ (昭和 55 年 10 月 24 日受理)
}

\section{Precursors to the Haicheng and Tangshan Earthquakes}

\author{
Jian-zhong ZHENG* \\ Department of Applied Physics, Faculty of Science, \\ Tokyo Institute of Technology
}

(Received October 24, 1980)

\begin{abstract}
Many precursory phenomena, both geophysical and biological, were reported in relation to the Haicheng $(M=7.3,1975)$ and Tangshan $(M=7.8,1975)$ earthquakes in China. Precursor times and epicentral distances of these premonitory effects are analysed by making use of the Weibull distribution which was extensively utilized by RIKITAKE $(1975,1978 \mathrm{a}, 1978 \mathrm{~b}$, $1979 \mathrm{a}, 1979 \mathrm{~b}$ ) and RIKITAKE and SuzuKI (1979).

Three kinds of precursor, each having a mean precursor time amounting to 418 days, 2.8 hours and 4.2 days respectively are found from the analysis for the geophysical precursors of the Haicheng earthquake. These precursors seem to coincide with the first, second and third precursors as defined by Rikitake (1979 a). On the other hand, the second or imminent precursor seems to have been missing for the Tangshan earthquake although the other two precursors having mean precursor times respectively amounting to 497 and 21 days seem to have been observed.

Mean precursor times for anomalous animal behavior are estimated as 7.8 and 0.6 days for the Haicheng earthquake, while only one peak of precursor time is obtained at 0.4 days for the Tangshan earthquake.

Maximum frequency of the epicentral distance of precursors seems to occur within a range $120-140 \mathrm{~km}$ for both the earthquakes.

The results of the present analysis do not differ much from those so far obtained for the distribution of precursor times for world-wide data and a few particular earthquakes. It may be that we may accomplish an earthquake prediction provided careful detection of possible precursors can be performed with a dense array of observation instruments covering an extensive area.
\end{abstract}

\section{§1. はじめに}

海城地震 $(M=7.3,1975)$ 及び唐山地震 $(M=7.8,1976)$ はそれぞれ中国の遼寧省南部及び 北京一天津一唐山地区に発生した。これらの地域には比較的高密度の専門観測点及び大衆観測 点がある.それらの各観測点では, 地震活動, 地款変動, 地磁気, 地電流, 重力, 地下水, ラ ドンなどの観測が行われていたので, 地震の発生に先行して, 多くの地震先行現象を観測する

* 現在の勤務先：中国科学院地球物理研究所 
鄭建 中

ことができた. このように, ある特定の地震の先行現象が多数観測されたことは, 地震予知研 究史上はじめてのことといえよう。この報文においては，これらの先行現象をとりまとめ，そ の先行時間及び震央距離を Weibull 分布 [RIKITAKE (1975, $1978 \mathrm{a}, 1979 \mathrm{ab})$ ；力武 (1978)； 力武・鈴木 (1979)] を用いて解析する.

\section{§2. デ 一 タ}

地学的先行現象のデータは, 主として中国に括いて正式に発表された出版物と日本の訪中団 報告書などによる，これらは蔣（1978）と陳他（1979）に基づき, また，朱 (1976), 地震学 会 (1978), 国立防災科学技術センター (1979), 力武 (1979c) なども参考にして得たもので ある．ここに取扱つたデータは全部とはいわないまでも，特に著しい先行現象の大部分をカバ 一していると考兄てさしつかえないと信じる．先行現象の震央距離は中国地図 [地図出版社, (1966) ] を用いて求めたが，その精度は今回の統計的解析に対しては十分である.これらのデ ータは APPENDIX 1 及び 2 にまとめてある.

地震に先行する動物異常行動の先行時間は主に ZHENG (1979) に基づき, 朱 (1976), 地震 学会 (1978), 国立防災科学技術センター (1979), 力武 (1979 c), 尾池 (1978) なども参考に して得られたものである.

\section{§3. 先行現象の震央距離の頻度分布}

海城地震の先行現象の中で震央距離のわかつているものは 58 個であり, 唐山地震について は 153 個である.ここでは震央距離の常用対数 $\log _{10} \Delta(\Delta$ の単位, $\mathrm{km})$ の頻度分布を調べる ことにする.

Fig. $1 \mathrm{a}$ および Fig. $1 \mathrm{~b}$ は海城地震及び唐山地震の先行現象について $\log _{10} \Delta$ のヒストグ ラムを示したものである. 図から, 二つのグラフの様子はよく似ており, 両者とも, $\log _{10} \Delta=$ 2〜2.25 のところにピークがあることがわかる.

動物異常行動については観測された地点の位置がはつきりしないため, $\log _{10} \Delta$ のヒストグ ラムを調べることはできなかつた。

\section{§4. 先行現象の先行時間の頻度分布}

先行時間のわかつている地学的先行現象のデータをとりまとめたところ, 海城地震では 61 個，唐山地震では 161 個となつた. 先行時間 $T$ を日数で表わしたときのヒストグラムを Fig. 2 に示した。図に見られるように，海城地震の場合の先行時間の三つのピークは，ちようど 


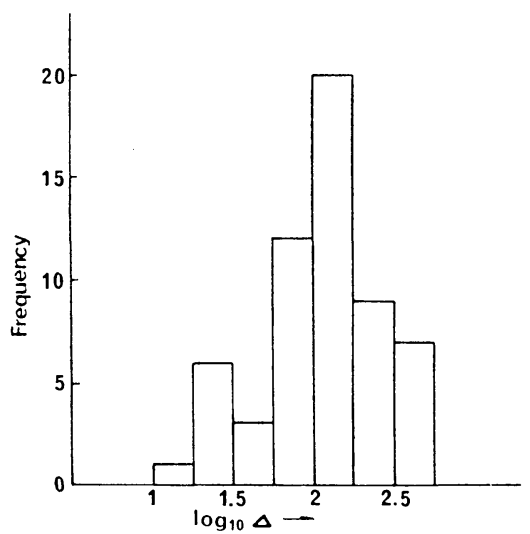

(a)

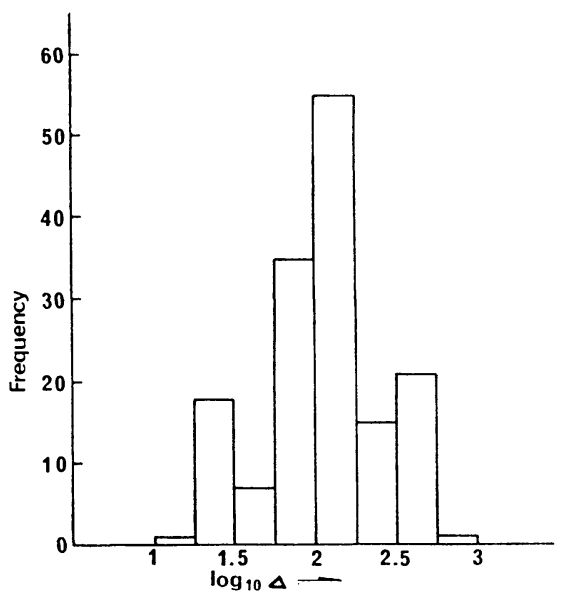

(b)

Fig. 1 a. The histogram of logarithmic epicentral distance $(\Delta$ in $\mathrm{km})$ for the precursors of the Haicheng earthquake.

$1 \mathrm{~b}$. The histogram of logarithmic epicentral distance $(\Delta$ in $\mathrm{km})$ for the precursors of the Tangshan earthquake.

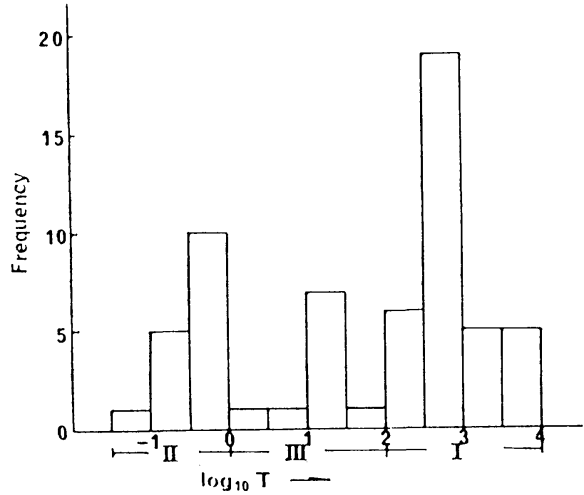

(a)

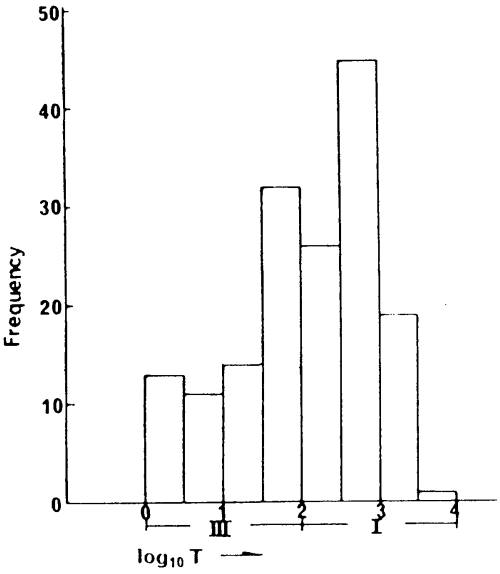

(b)

Fig. 2 a. The histogram of logarithmic precursor time ( $T$ in days) of geophysical precursors for the Haicheng earthquake.

$2 \mathrm{~b}$. The histogram of logarithmic precursor time ( $T$ in days) of geophysical precursors for the Tangshan earthquake.

I, II and III denote the precursors of the first, second and third kinds, respectively. 


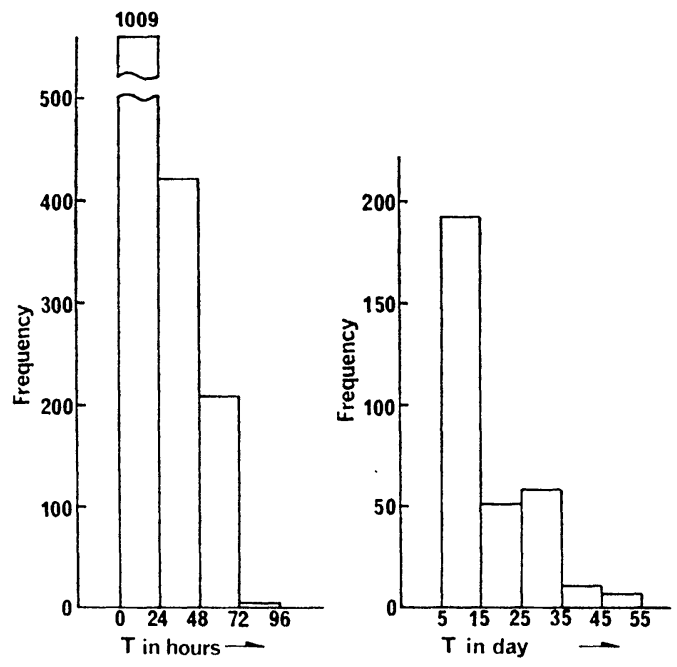

(a)

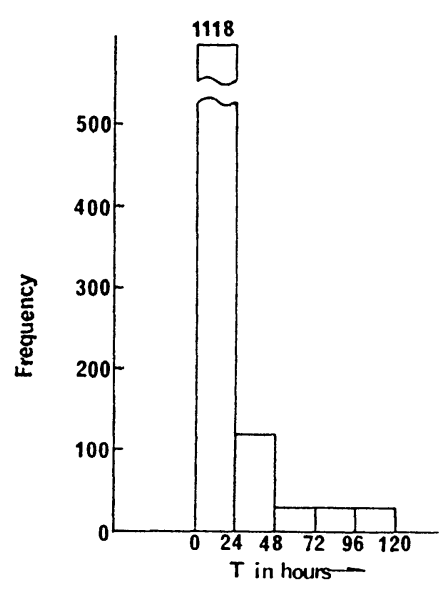

(b)

Fig. 3 a. The histogram of precursor times for anomalous animal behaviour in the case of the Haicheng earthquake.

$3 \mathrm{~b}$. The histogram of precursor times for anomalous animal behaviour in the case of the Tangshan earthquake.

RIKITAKE（1979 a) によつて分類された第 1，第 2, 第 3 種先行現象の先行時間に対応して いる. 唐山地震の場合には第 1 , 第 3 種先行現象は見られるが第 2 種先行現象に相当する先 行時間帯に観測例が報告されていないので，第 2 種先行現象が存在したか否かはわからない.

ZHENG (1979) に基づいて, 海城地震の動物異常行動の先行時間の頻度分布を調べた. 地震 直前の 5 日間のデータについては， $T$ を時間で表わし，それ以前のデータについては $T$ を日 数で表した。前者の場合には 24 時間を時間間隔とし，また後者の場合には 10 日間を間隔と して Fig. 3 a に示すヒストグラムが得られた.

唐山地震の場合には, 先行時間 $T$ を時間で表わし, 間隔 24 時間で Fig. $3 \mathrm{~b}$ に示すとス トグラムを得た。図から明らかのように海城地震に先行する動物異常行動の先行時間のピーク は二つあり，唐山地震の場合には，一つしかないということがわかる.

\section{§5. Weibull 分布による解析}

海城地震及び唐山地震の先行現象の先行時間及び震央距離の 頻度分布を解析するために Weibull 分布を用いる.

ある地震が時刻 $s$ 以前に起つていないとして， $s$ と $s+\Delta s$ との間に起る確率を入 $(s)$ とする. ここに $\lambda(s)$ は, Weibull 分布 


$$
\lambda(s)=K s^{m}
$$

で表わされると仮定する. $K$ と $m$ は定数で, $K>0, m>-1$ とする.

$0 \sim s$ の間に地震が発生する集積確率を $F(s)$ とし, 信頼度関数 $R(s)$ を

$$
R(s)=1-F(s)
$$

で定義すれば

$$
R(s)=\exp \left[-\int_{0}^{s} \lambda(s) d s\right]=\exp \left(-\frac{K s^{m+1}}{m+1}\right)
$$

となる。

地震が起る確率密度 $f(s)$ は,

$$
f(s)=-\frac{d R(s)}{d s}=K s^{m} \exp \left(-\frac{K s^{m+1}}{m+1}\right)
$$

で与えられる.

したがつて, $s$ の平均值は,

$$
E[s]=\int_{0}^{\infty} s f(s) d s=\left(\frac{K}{m+1}\right)^{-1 /(m+1)} \Gamma\left(\frac{m+2}{m+1}\right)
$$

で与えられる.ここに $\Gamma$ は Gamma 関数である.

$$
E\left[s^{2}\right]=\int_{0}^{\infty} s^{2} f(s) d s=\left(\frac{K}{m+1}\right)^{-2 /(m+1)} \Gamma\left(\frac{m+3}{m+1}\right)
$$

であるので，その平均値の標準偏差は，

$$
\sigma[s]=\left(E\left[s^{2}\right]-E^{2}[s]\right)^{1 / 2}=E[s]\left[\Gamma\left(\frac{m+3}{m+1}\right)-\Gamma^{2}\left(\frac{m+2}{m+1}\right)\right]^{1 / 2} / \Gamma\left(\frac{m+2}{m+1}\right)
$$

となる。

$1 / R$ の二重自然対数をとれば，（3）より

$$
\log _{e} \log _{e}\left(\frac{1}{R}\right)=\log _{e} \frac{K}{m+1}+(m+1) \log _{e} s
$$

という関係が得られる。

式 (8) で $\log _{e} \log _{e}(1 / R)$ と $\log _{e} s$ の間には直線関係が成立する.

$\Delta s$ 間隔の各区間のらち, $i$ 番目の区間 $i \Delta s$ と $(i+1) \Delta s(i=0,1,2, \cdots)$ の間に $s$ が入る 確率密度 $f_{i}$ は 


$$
f_{i} \Delta s=n_{i} / N
$$

で与えられる. ここで $n_{i}, N$ はそれぞれ $i$ 番目の区間にある $\log _{e} s$ の数, データの総数を 表わす。したがつて集積確率は，

$$
F=\Delta s \sum_{i=1}^{i} f_{i}=\sum_{i=1}^{i} n_{i} / N
$$

となる。

したがつて， $F$ 及び $R$ は実際のデータより求められる. さらに式 (8) の $\log _{e} \log _{e}(1 / R)$ と $\log _{e} s$ との直線関係を用いて最小自乗法によりパラメーター $K$ 及び $m$ を求めることがで きる.

このようにして決定された $K$ と $m$ を用いて平均值 $E[s]$ 及び標準偏差 $\sigma[s]$ を計算する ことができる。

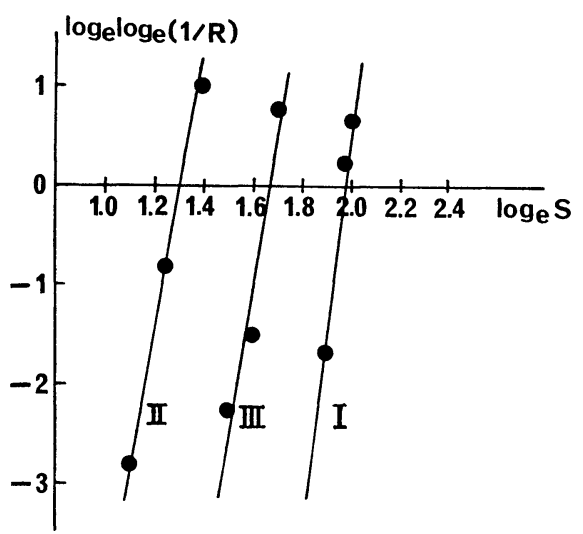

Fig. 4. $\log _{e} \log _{e}(1 / R)$ vs. $\log _{e} s$ plots for geophysical precursors of the Haicheng earthquake. I, II and III denote the precursors of the first, second and third kinds, respectively.
以上の方法を海城地震の各種地学的 先行現象に適用した結果が Fig. 4 で ある、これから，パラメーター $K$ 及 び $m$ を求めて，式 (5) 及び (7) を 地学的先行現象の先行時間に適用し, その平均值と標準偏差を求めた。その 結果は Table 1 に示してある。また 唐山地震についての同様の解析結果も 同表に示してある。さらに動物異常行 動の先行時間に関する同様の解析結果 は Table 2 にまた震央距離について の解析結果は Table 3 に示してある.

Table 1. Mean precursor time $E[T]$ and its standard deviation $\delta[T]$ for respective analyses.

\begin{tabular}{lccccc}
\hline & $\begin{array}{c}\text { Precursor of the first } \\
\text { kind (days) }\end{array}$ & $\begin{array}{c}\text { Precursor of the second } \\
\text { kind (hours) }\end{array}$ & $\begin{array}{c}\text { Precursor of the third } \\
\text { kind }\end{array}$ \\
\hline (days)
\end{tabular}


Table 2. Mean precursor time $E[T]$ and its standard deviation $\delta[T]$ for anomalous animal behaviour.

\begin{tabular}{lccl}
\hline \hline \multicolumn{1}{c}{ Analysis } & $E[T]$ (days) & $\delta[T]$ (days) & \multicolumn{1}{c}{ Reference } \\
\hline Rikitake's world-wide data & 0.4 & 0.9 & RIKITAKE (1978 a) \\
Miyagiken-Oki earthquake & 0.07 & 2.0 (hours) & RIKITAKE and SUzUKI \\
Near Izu-Oshima Island & 0.6 & 0.03 & $\begin{array}{l}\text { (1979) } \\
\text { earthquake }\end{array}$ \\
Haicheng earthquake & 7.8 & 0.2 & RIKITAKE (1978 b) \\
Tangshan earthquake & 0.6 & 10.1 & \\
\hline
\end{tabular}

これらの解析における $\log _{e} \log _{e}(1 / \mathrm{R})$ vs. $\log _{e} s$ プロットの図は省略する. なお，比較のために Table 1 には， RIKITAKE (1979 a) によつて求められ た既存の汎世界的データ及び伊豆大島 近海地震の際の平均值 $E[T]$ と標準 偏差 $\sigma[T]$ をも記してある。また， Table 2 には地震に先行する動物異常 行動について, 沉世界的データや伊豆 大島近海地震, 及び宮城県沖地震のデ ータより求められた先行時間の平均值 $E[T]$ と標準偏差 $\sigma[T]$ をも記して ある。

\section{§6. 考察}

（1） Table 1 によると, 海城地震 及び唐山地震の第 1 種先行現象の先行
Table 3. Mean epicentral distance $E[\Delta]$ and its standard deviation $\delta[4]$.

\begin{tabular}{cccc}
\hline \hline \multicolumn{2}{c}{ Haicheng earthquake } & \multicolumn{2}{c}{ Tangshan earthquake } \\
\hline$E[\Delta](\mathrm{km})$ & $\delta[\Delta](\mathrm{km})$ & $E[\Delta](\mathrm{km})$ & $\delta[\Delta](\mathrm{km})$ \\
139 & 96 & 123 & 113 \\
\hline
\end{tabular}

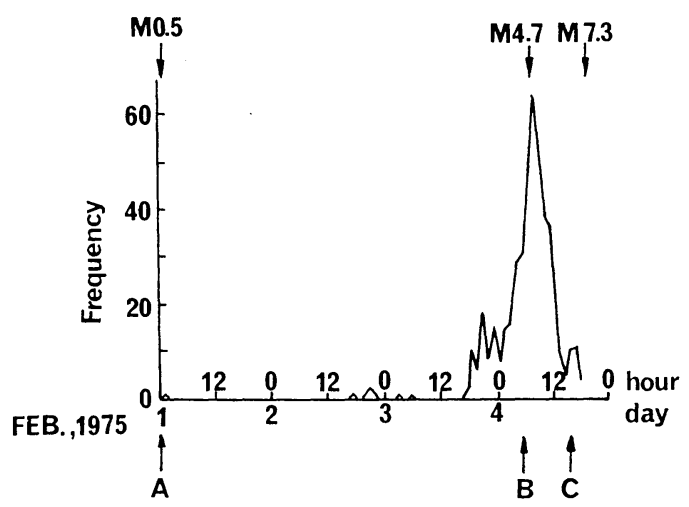

Fig. 5. Changes in the number of foreshocks of the Haicheng earthquake and the mean precursor times. A: Mean precursor time for the third kind precursor; B: Mean precursor time for the second kind precursor; C: Mean precursor time for anomalous animal behaviour.

時間の平均値はそれぞれ 418 日，497 日である.また, 実際のデータの分布範囲は APPENDIX 1 及び 2 によりそれぞれ $360 \sim 4320$ 日，330 3600 日であるが，それは海城地震及び唐山地 震の長中期的予測が行なわれた期間に相当する [蔣 (1978); 陳地 (1979)].

（2）海城地震の第 2 種先行現象の先行時間の平均値 2.8 時間は, 沉世界的データの平均 值 2.4 時間に近い，海城地震直前 2.8 時間といらのは, ちようど前震の頻度分布における 2 
番目のピークに相当する (Fig. 5 の“B”). 唐山地震については，第 2 種先行現象に対応する 観測例がないようである.

（3）海城地震の第 3 種先行現象の先行時間の平均值 4.2 日は汎世界的データの平均价 4.5 日によく一致する (Table 1). 海城地震前 4.2 日即ち 2 月 1 日午前 1 時ごろは Fig. 5 に見ら れるようにちようど最初の前震 $(M=0.5)$ が起り始めた時期である. 唐山地震の第 3 種先行 現象の先行時間の平均值 21.8 日は沉世界的データの平均值 4.5 日より大きいが，伊豆大島近 海地震の先行現象の先行時間の平均値数十日 [RIKITAKE (1979 b)] に近い值である (Table 1).

（4）海城地震の動物異常行動の先行時間の頻度分布には 2 つのピークがあり (Fig. 3 a), その平均值はそれぞれ 7.8 日，0.6 日である．7.8 日という先行時間は沉世界的データの平均 值よりかなり長い。0.6 日といら先行時間は，海城地震の前震が最も頻繁に発生した時間带や 最大の前震 $(M=4.7)$ が発生した時刻とよく一致する (Fig. 5). 唐山地震については, 動物 異常行動の先行時間の平均值は 0.4 日である. それらの 0.6 日及び 0.4 日という先行時間は沉 世界的データの平均值及び伊豆大島近海地震について求められた先行時間の平均值とあまり違 わない. しかし，超短期的先行時間をもつ動物異常行動については，報告例がないようである.

（5） Table 1 及び 2 からみると, 海城地震と唐山地震とでは, 先行現象の種類や時間帯 に異なるところがある，そういら両者の違いは，地震の類型の違いと関係があると思われる. なぜなら，海城地震は「前震一本震一余震」型 [吴他 (1976)] であり, 唐山地震は「本震一余 震」型 [馬 (1978) ] であるからである. Fig. 5 に見られるように, 前震に伴ら海城地震の第 3 種及び第 2 種先行現象の先行時間の平均値と短期的動物異常行動の先行時間の平均値の 3 種類 の先行時間は, それぞれ海城地震の最初の前震 $(M=0.5)$ の起つた時期, 前震の頻度分布の 2 番目のピークの出現した時期及び最大前震の起つた時期にかなり良く一致している. 唐山地震 では前震がなかつたので第 2 種先行現象が見られず，第 3 種先行現象の平均先行時間はかなり 長いほうにずれた。

（6） Fig. 1 からは, 地震先行現象が観測された地点の震央距離の頻度分布は海城地震も唐 山地震も大体同じであることがわかる．その頻度分布のピークは両者とも $\log _{10} \Delta=2.0 \sim 2.25$ のあたりにあり，その平均值はそれぞれ $139 \mathrm{~km}$ 及び $123 \mathrm{~km}$ である。鄭他 (1979) によると， 唐山地震前に, 地下水異常下降値が一番早く起つた地点の震央距離は $100 \mathrm{~km}$ 前後であつたよ らである。 また馬（1978）によると，海城地震及び唐山地震前 3 年間の地震活動は長軸半径 $150 \mathrm{~km}$, 短軸半径 $100 \mathrm{~km}$ の棈円状の範囲に分布する. 上に求めた平均の震央距離は, この 範囲に入るので, この範囲内で, 海城地震及び唐山地震の発生につながるストレスの集積など の地学的諸過程が進行したものと思われる. 
（7）APPENDIXI 1 及び 2 から見ると, ある特定の方法で観測された先行現象の中に は, 先行時間に広がりがあり, 第 1 種から第 3 種まで対応する先行現象が存在する. 例えば地 殻変動, 地電流, 電気比抵抗, 地磁気, 重力, ラドンなどの方法で観測した先行現象には, 第 1 種から第 3 種までのすべての先行現象が存在する. よつて, RIKITAKE (1979 a) の第 1 種先 行現象の先行時間は, 各方法で観測した先行現象の先行時間の上限を与えたに過ぎない。しか 乙, 震央距離と関係のない力法, 例兄ば地震波速度比 $V_{p} / V_{s}, b$ 值, 微小地震の震源入カニズ ムなどの観測方法で得られた先行現象には, 第 1 種先行現象しか存在しない.

（8）Fig. $2 \mathrm{a}$ 及び $2 \mathrm{~b}$ はそれぞれ海域地震及び唐山地震の地学的先行現象の先行時間の 頻度分布であるが, Fig. $3 \mathrm{a}$ 及び $3 \mathrm{~b}$ に示した動物異常行動の先行時間の頻度分布とは著し く異なつた分布を示すことは與味深い. 地学的先行現象と動物異常先行現象では先行時間の頻 度分布のピークが見られる時間が違う。したがつて，海城地震及び唐山地震の動物異常先行現 象の先行時間は, 地学的先行現象の先行時間と異なつた分布となる.つまり，この二つの先行 現象は，相補的であるということになる。

\section{§7. おわりに}

海城地震及び唐山地震の先行時間の頻度分布をWeibull 分布を用いて解析したところ, RIKITAKE（1979 a, 1978 a) が沉世界的データから求めたような各種地学的先行現象と動物異 常先行現象が, 海城地震及び唐山地震の場合にも先行現象として存在することが明らかとなつ た。 また，その平均先行時間は地震によつて異なることもあるらしいことがわからた。

このような結果から判断して，長期予報が出されている地域に频いて観測を強化継続してい るならば, 第 3 種先行現象の出現を経て, 第 2 種先行現象をキャッチすることができるものと思 われる，即ち，この異常をいわゆる直前予報として，地震警報に結びつけることができると期 待される．事実，中国の海城地震の場合には，長期，中期，短期及び臨震の各段階 [蔣 (1978); 朱(1976) ] をふんで，地震警報発令となつた：をた，動物異常先行現象は，補助的役割を果す であろら。

上述の議論によると, 地震予知が全く「不可知」, 「五里霧中」というわけではないことがわ かる．海城地震の予知が成功したことがその有力な証拠ではないかと思われる．勿論, 的確な 科学的予知には，まだまだほど遠いことは明らかであり，今後ともより多くのデータの取得及 び予知理論の完成に向けて，一層努力を続けなければならない. 


\section{§8. 謝 辞}

この論文を終るにあたり，指導教官としていろいろ指導して下さり，いろいろ配慮して下さ り，いろいろの文献と著作を拝読させて下さつた力武常次教授に深く感謝申し上げます。

なお，本蔵義守助教授，田中秀文助手をはじめ，研究室の皆様にもいろいろお世話になりま した．田中秀文助手には直接手伝つていただき，数々の討論をしていただき，入手しにくい文 献の便宜を計つて下さいました。

このよらに多くの皆様に支えられて，この論文ができたことを思い，心から感謝しつつ筆を おく次第です。

\section{文献}

馬鴻度，1978，華北地区幾次大震前的 b 值異常变化，地球物理学報， 21，126-141.

陳 非比・張 建華・劉 秉良・商 宏寛 (編著), 1979 , 唐山地震, 地震出版社, 北京, $145 \mathrm{pp}$.

地図出版社 (編), 1966, 中国地図册, 地図出版社, 北京, $35 \mathrm{pp}$.

吴 開統・岳明 生・武 宦英・曹新 玲・陳 海通・黄 偉琼・田 抗援・芦 寿徳, 1976, 海城地震 序列的特征, 地球物理学報, 19, 95-109.

地震学会, 1978,1977 年地震学会訪中代表団報告集, 地震学会, 東京, $154 \mathrm{pp}$.

国立防災科学技術センター，1979，中国の地震予知の現状一1978 年訪中地震予知調査団の報告一, 国立防 災科学技術センター, 東京, $169 \mathrm{pp}$.

尾池和夫, 1978, 中国の地震予知, 日本放送出版協会, 東京, $235 \mathrm{pp}$.

Rikitake, T., 1975, Earthquake Precursors, Bull. Seismol. Soc. Am., 65, 1133-1162.

Rikitake, T., 1978 a, Biosystem Behaviour as an Earthquake Precursor, Tectonophysics, 51, 1-20.

力武常次， $1978 \mathrm{~b}$ ，伊豆大島近海地震と動物先行現象，地震予知連絡会会報， 20, 67-76.

Rikitake, T., 1979 a, Classification of Earthquake Precursors, Tectonophysics, 54, 293-309.

Rikitake, T., $1979 \mathrm{~b}$, Precursors to the 1978 Near Izu-Oshima Island, Japan, Earthquake of Magnitude 7.0. In: T. Rikitake (Editor), Current Research in Earthquake Prediction I,

Center for Academic Publication Japan/Japan Scientific Societies Press, Tokyo, in press.

力武常次, $1979 \mathrm{c}$, 地震予報・警報論, 学会誌刊行センタ一, 東京, $371 \mathrm{pp}$.

力武常次・鈴木美音子， 1979，宮城県沖地震と動物先行現象，地震予知連絡会会報， 21，28-37.

蔣凡 (編著), 1978, 海城地震, 地震出版社, 北京, $90 \mathrm{pp}$.

朱鳳 鳴, 1976 , 海城に発生した $M 7.3$ の地震に関する予知・予報と防㷋の概況, 地震学会(編), 中国地 震考察団講演論文集, 地震学会, 東京, 15-26.

鄭 治真 - 劉元 壮・胡 作春・呂苑 苑 - 景 天永 - 張 雌国, 1979 ，根据地下水資料的数字濾波探討 唐山大震的孕育過程, 地球物理学報, 22, 267-279.

ZHENG, G.Z., 1979, Some Characteristics of Animal Behavior Prior to Earthquakes, Proceedings of the UNESCO Symposium on Earthquake Prediction, in press. 


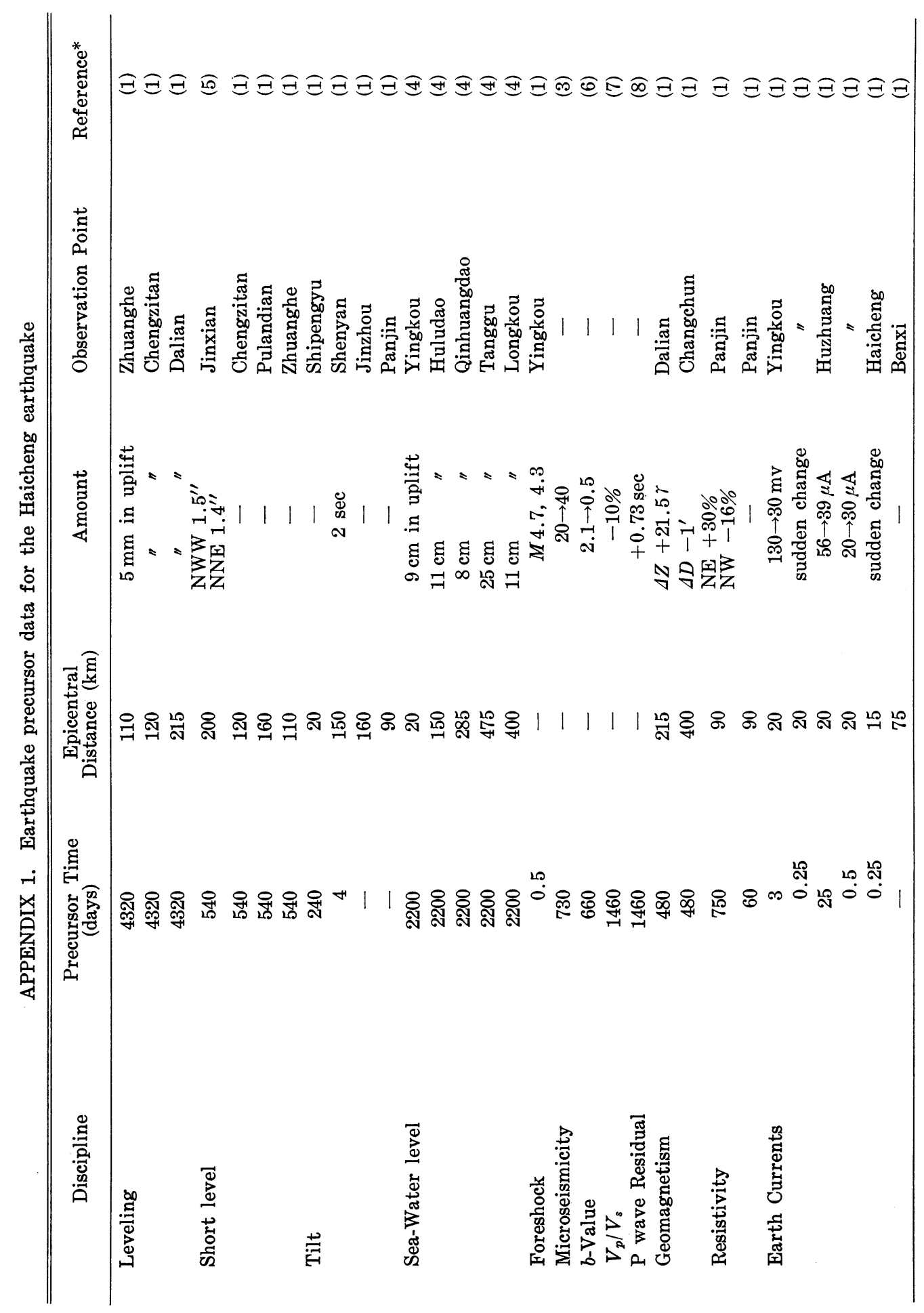




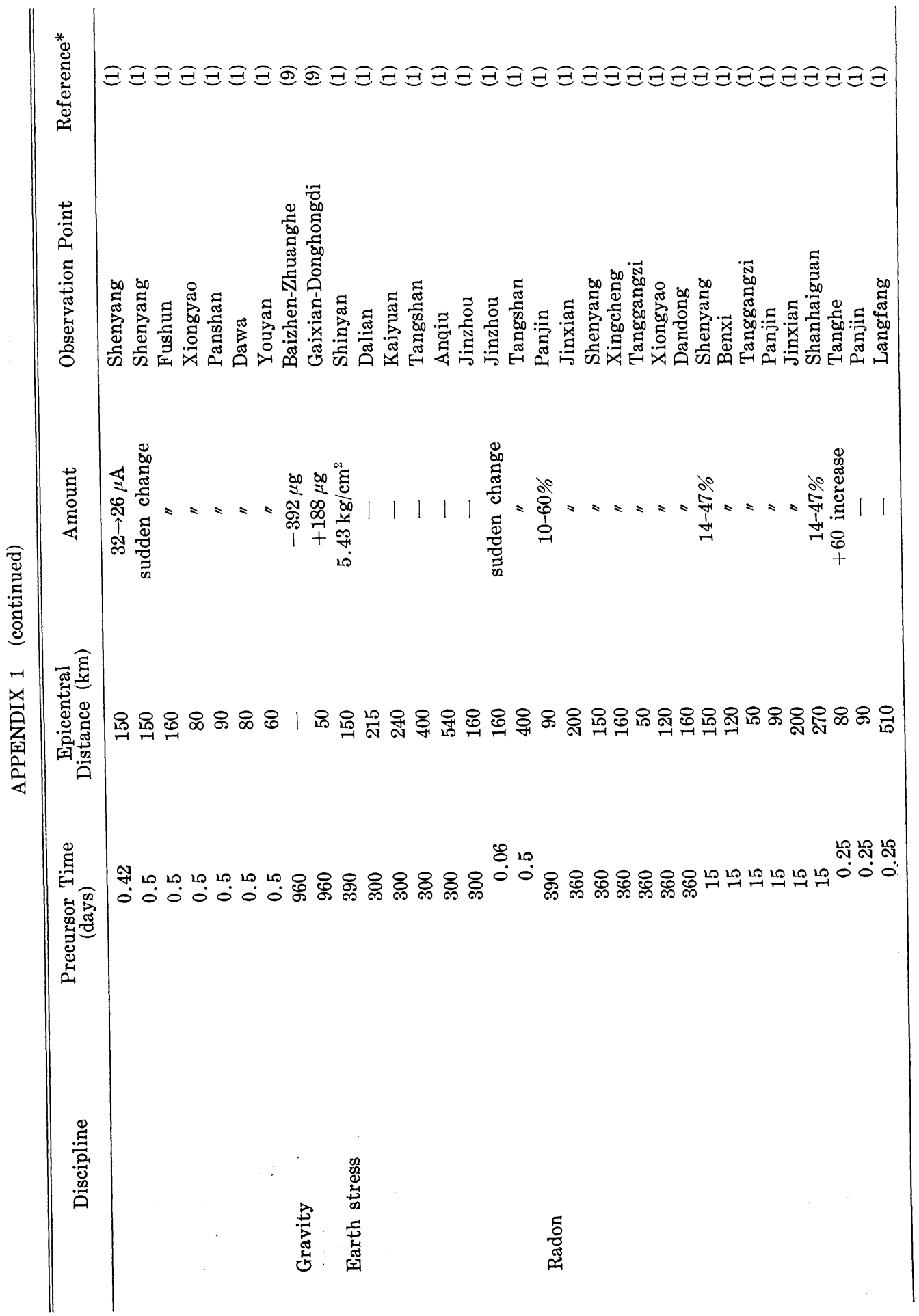




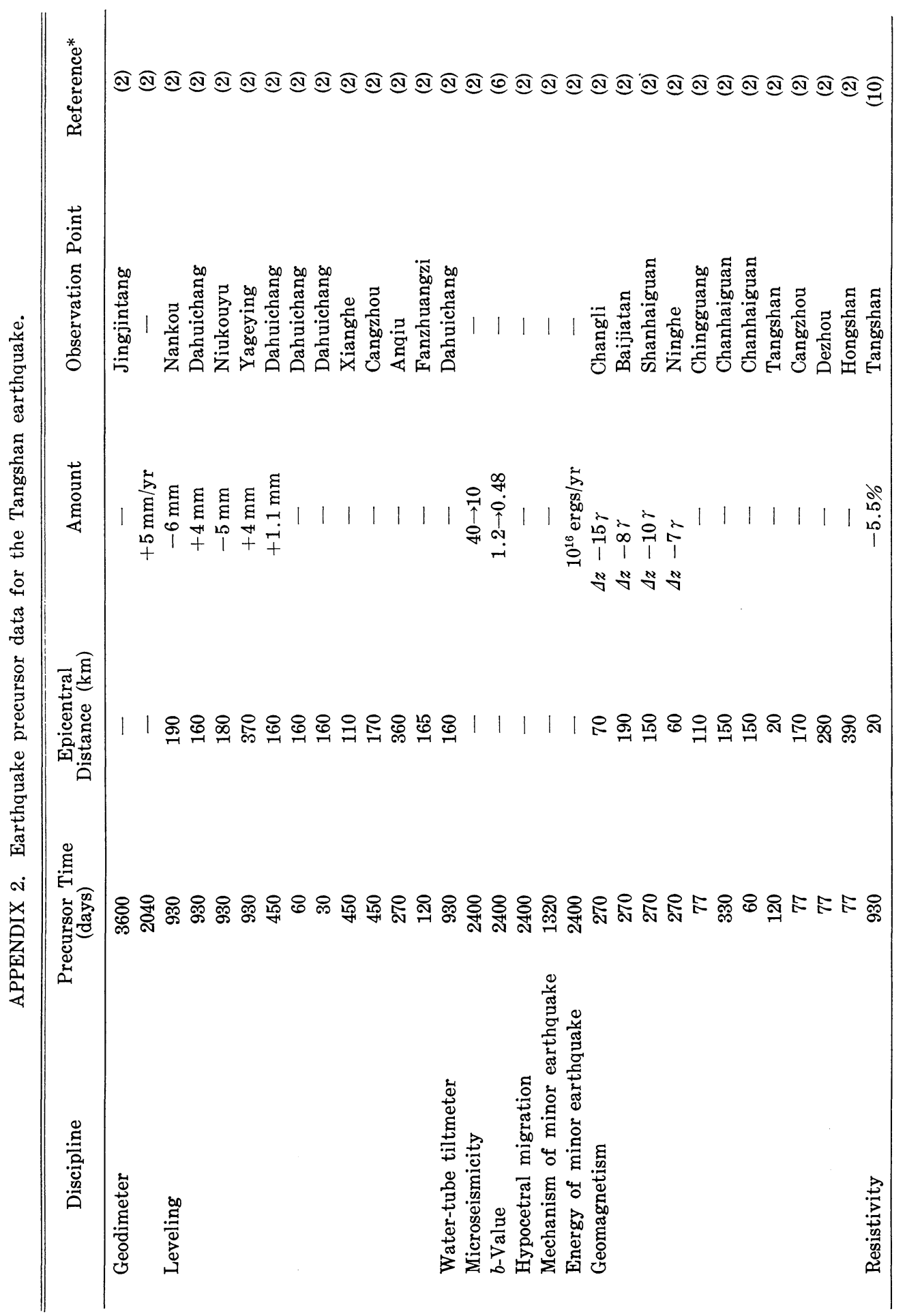




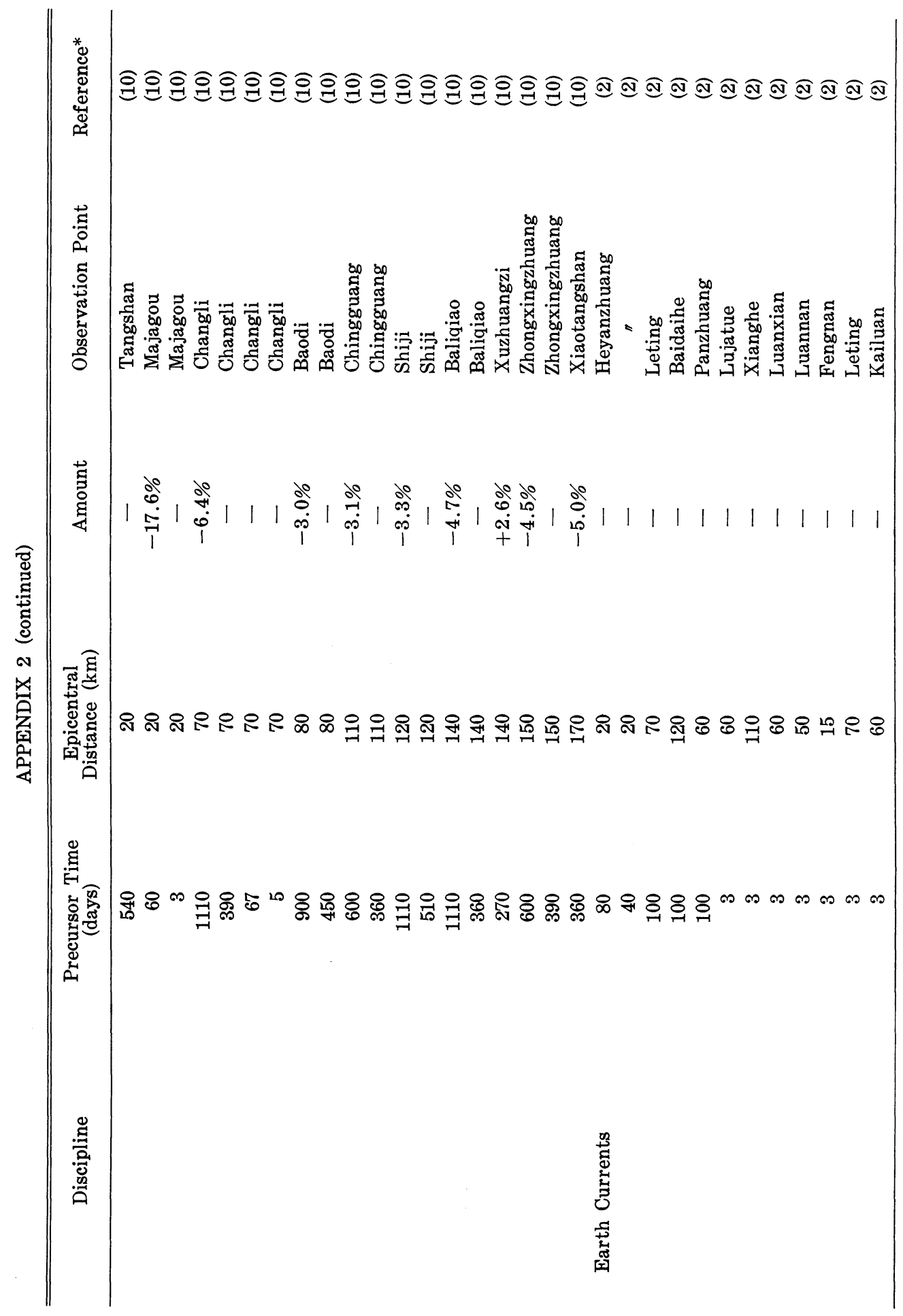




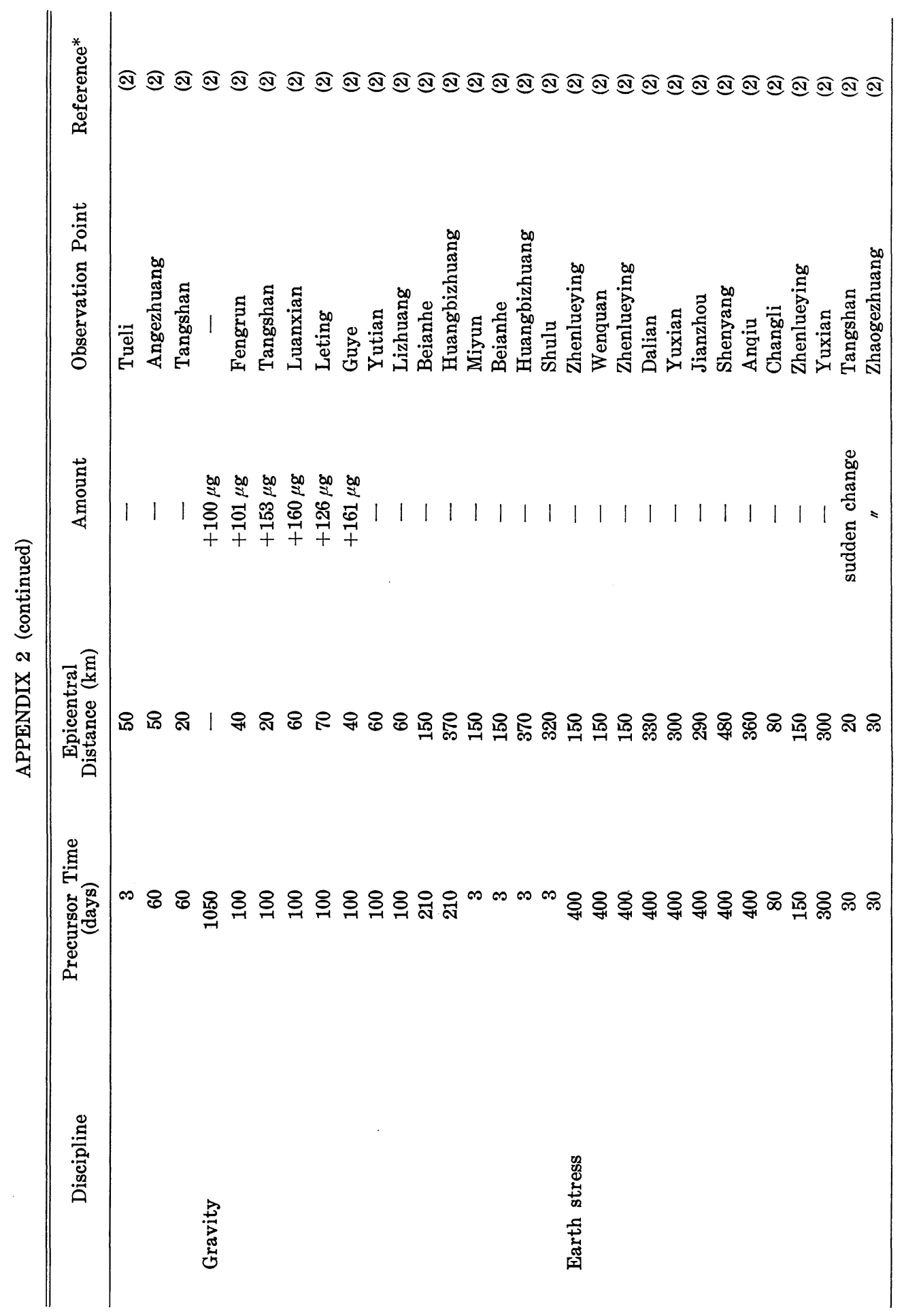




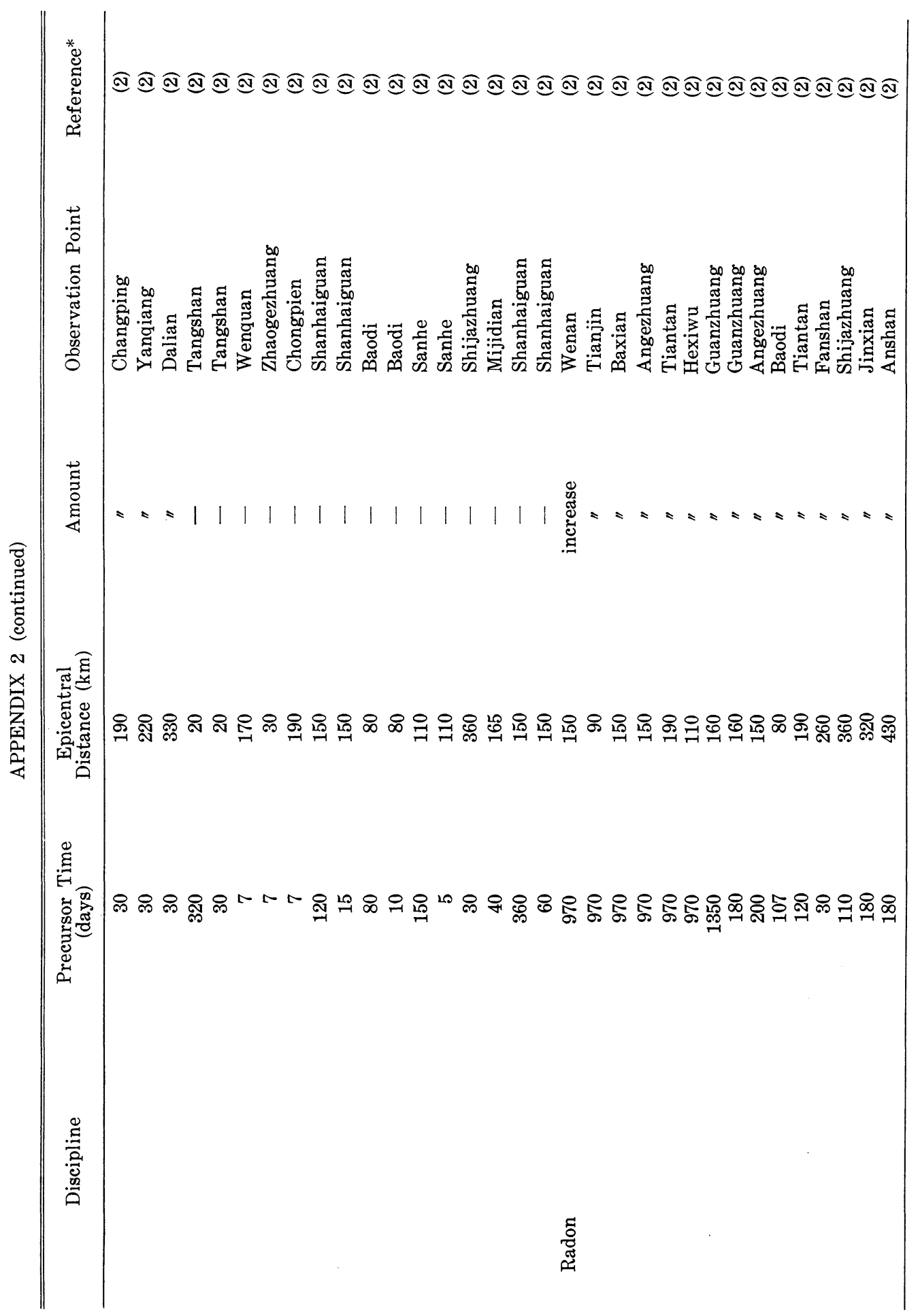




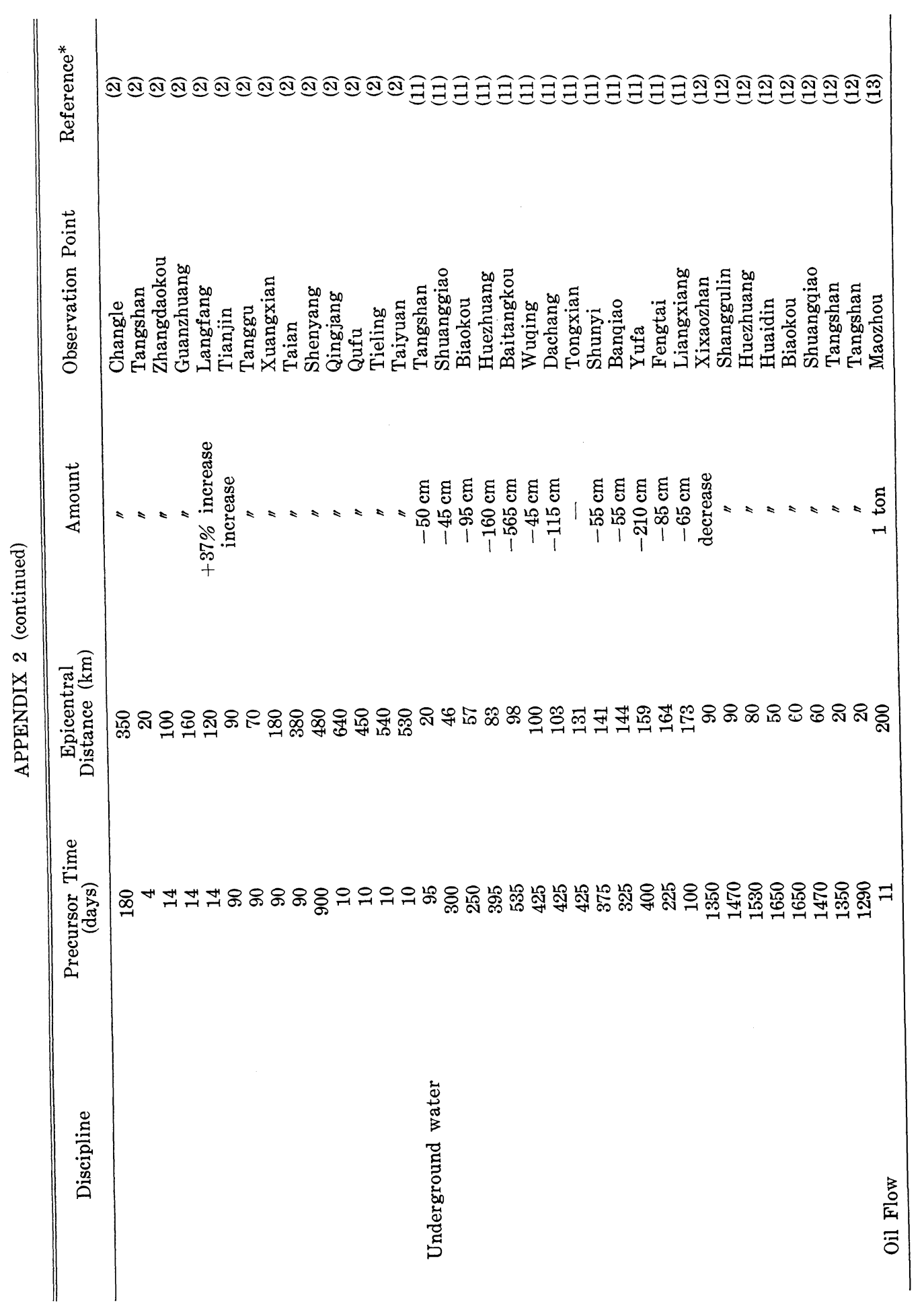

